\title{
YEAST SPECIES FOR BIOCONTROL OF APPLE POSTHARVEST DISEASES : AN ENCOURAGING CASE OF STUDY FOR PRACTICAL USE
}

\author{
M. Haïssam Jijakli, Philippe Lepoivre and Cathy Grevesse \\ Unité de Phytopathologie, Faculté Universitaire des Sciences Agronomiques, \\ 2, Passage des Déportés, B-5030 Gembloux, Belgium
}

\section{INTRODUCTION}

Since early 1970's, postharvest diseases of apple annually cause losses of 15-25\% despite modern storage facilities including controlled atmosphere (CA) or Ultra Low Oxygen (ULO) facilities (Bondoux, 1992). Factors that favour microbial growth, such as physiological senescence of fruits, mechanical injuries, as well as physiological disorders due to undesirable storage conditions can promote and explain these postharvest decays.

In Belgium and France (Bondoux, 1992) most losses are attributable to Penicillium expansum LK, Botrytis cinerea Pers. and Gloeosporides sp. (including Cryptosoporiopsis malicorticis (Cordl.) Nannf., Colletotrichum gloeosporioides (Penz.) and Trichoseptoria fructigena Maubl.). In USA and UK, Botrytis and Penicillium are the most important agents of postharvest diseases (Rosenberger, 1991). During storage, wounds are the first sites of fection for the initiation of diseases caused by the grey mould ( $B$. cinerea) or the blue mould ( $P$. expansum) agents. Both fungal agents infect fruits by deposit of airborne or waterborne conidia on wounds during harvesting and handling before storage. Infections of the Gloeosporides sp. occur in the field but quiescent latent and escape notice at harvest (Bondoux, 1992).

Control measures are principally based on the protection of fruits from pre- and postharvest infection with pre- and postharvest fungicide treatments. However, in the context of consumer reluctance to chemical residues in food and public concern for environmental safety, there is an increasing demand to develop alternative methods to control diseases. That demand becomes a critical weed with respect to the possible deregistragion of effective and widely used fungicides (Wellings, 1996) and the development of fungicide-resistant strains of postharvest pathogens (Franclet, 1994). Several novel approaches are emerging as possible 
2. alternatives to synthetic fungicides, including induction of natural defence mechanisms of harvested products, application of natural biocides, genetic resistance, and biological control agents (BCA's) (Wilson et al., 1994).

The first phases of development of a biological control product can be considered as being very similar to the development of a chemical pesticide: early screening of a reliable activity, high efficacy in realistic conditions and adequate formulation to meet the expectation of the growers. However, because biological control agents (BCA) used for the control of plant diseases are primarily living organisms, their mass production, the study of their mode of action and their safety requirements are likely to be somewhat different than those for chemical pesticides. Public policy must translate that specificity in homologation procedures based on a case by case study.

Although the relevance of BCA appears limited until now, biological control of postharvest diseases are often presented as a specially promising area as testifying by already commercialised agents. In this respect, the paper exemplifies the potential and limits of such biocontrol strategy by presenting the case study of two yeast's, Pichia anomala (strain K) and Debaryomyces hansenii (strain O) exhibiting high and reliable protective activity agair Penicillium sp. and Botrytis cinerea in postharvested apples.

\section{POSTHARVEST DISEASES OF FRUITS : A PREDILECTION FIELD OF BIOLOGICAL CONTROL}

Biological control is generating a great enthusiasm to play a role in sustainable agriculture although the relevance of BCA's in plant pathology appears limited until now. If everybody recognises the existence of natural phenomenon's of microbial antagonism, the question is to know how to manipulate naturally occurring antagonistic micro-organisms to achieve a reliable and effective strategy of disease control meeting the requirements of the market. In this respect, postharvest biological control could be considered as specially promising on a practical point of view because (1) the application sites are limited to the fruits, (2) the environmental conditions are defined and stable in storage rooms, and (3) the harvested commodities are of high value.

Literature presents numerous examples of biocontrol of fruit diseases (Table 1). Furthermore, biocontrol products such as Biosave ${ }^{\mathrm{TM}}$ (Pseudomonas syringae van Hall, Esc11) and Aspire ${ }^{\mathrm{TM}}$ (Candida oleophila Montrocher, I-182) are already commercialised by Ecogen Inc. (Longhorn, PA) and Ecoscience Corp. (Worcester, MA), respectively and are used among other on postharvest apples against wound diseases.

Before becoming an economically feasible alternative to chemical control, BCA's have to satisfy different requirements related to biological, technological and toxicological properties. We will review the requirements that an "ideal antagonist" must meet through our research dealing with the biological protection of postharvest apples. An "ideal antagonist" should have the following characteristics: effective at low concentrations in several postharvest host pathogen combinations; able to survive under adverse environmental conditions such as low temperatures and conrolled atmospheres adopted prevailing in storage facilities; amenable to inexpensive production and formulation with a long shelf life; easy to dispense; compatible with commercial handling practices; genetically stable ; non pathogenic for the consumer and for the host commodity. 
Table 1. Examples of BCA's used to control diseases on apples

\begin{tabular}{|c|c|c|c|c|}
\hline Disease & Antagonist & $\begin{array}{l}\text { Nature of } B C A \text { and } \\
\text { application period }\end{array}$ & Mode of action & Reference \\
\hline \multirow[t]{4}{*}{ B. cinerea } & $\begin{array}{l}\text { Trichoderma } \\
\text { pseudokoningii }\end{array}$ & $\begin{array}{l}\text { Fungus, blossoming to } \\
\text { harvest }\end{array}$ & $\begin{array}{l}\text { Parasitism and } \\
\text { antibiosis }\end{array}$ & $\begin{array}{l}\text { Tronsmo and } \\
\text { Ystaas (1980) }\end{array}$ \\
\hline & Trichoderma harzianum & $\begin{array}{l}\text { Fungus, blossoming to } \\
\text { harvest }\end{array}$ & Parasitism & $\begin{array}{l}\text { Tronsmo and } \\
\text { Ystaas (1980) }\end{array}$ \\
\hline & $\begin{array}{l}\text { Metschnikowia } \\
\text { pulcherrima }\end{array}$ & Yeast, storage & Competition & Piano et al., (1997) \\
\hline & $\begin{array}{l}\text { Cryptococcus humicola, } \\
\text { Filobasidium floriforme, } \\
\text { Rhodosporidium toruloides }\end{array}$ & Yeast's, storage & Competition & $\begin{array}{l}\text { Filonow et al., } \\
\text { (1996) }\end{array}$ \\
\hline \multirow[t]{5}{*}{$\begin{array}{l}\text { B. cinerea and } \\
\text { P. expansum }\end{array}$} & Pseudomonas cepacia & $\begin{array}{l}\text { Bacteria, storage } \\
\text { (pyrrolnitrine) } \\
\text { and competition }\end{array}$ & Antibiosis & $\begin{array}{l}\text { Janisiewicz and } \\
\text { Roitman (1988); } \\
\text { Chalutz and Droby } \\
\text { (1993) }\end{array}$ \\
\hline & Acremonium breve & Yeast, storage & $\begin{array}{l}\text { Competition and } \\
\text { induction of host } \\
\text { resistance }\end{array}$ & $\begin{array}{l}\text { Janisiewicz (1987, } \\
\text { 1988) }\end{array}$ \\
\hline & Cryptococcus laurentii & Yeast, storage & Competition & $\begin{array}{l}\text { Roberts (1991); } \\
\text { Wilson et al.,(1993); } \\
\text { Chalutz and Droby } \\
\text { (1993) }\end{array}$ \\
\hline & Pichia guilliermondii & Yeast, storage & $\begin{array}{l}\text { Competition, } \\
\text { parasitism }\end{array}$ & $\begin{array}{l}\text { Wilson and } \\
\text { Wisniewski (1989); } \\
\text { Chalutz and Droby } \\
\text { (1993) }\end{array}$ \\
\hline & $\begin{array}{l}\text { Trichosporon sp. and } \\
\text { Candida sp. }\end{array}$ & Yeast, storage & Competition & Aloi et al., (1991) \\
\hline \multirow{2}{*}{$\begin{array}{l}\text { B. cinerea, } \\
P . \text { expansum; } \\
\text { and Mucor sp. }\end{array}$} & $\begin{array}{l}\text { Pseudomonas syringae } \\
\text { (Biosave ä)* }\end{array}$ & Bacteria, storage & $\begin{array}{l}\text { Induction of host } \\
\text { resistance }\end{array}$ & $\begin{array}{l}\text { Ecogen Inc. } \\
\text { (Longhom, PA) }\end{array}$ \\
\hline & $\begin{array}{l}\text { Candida oleophila } \\
\text { (Aspire à)* }\end{array}$ & Yeast, storage & Competition & $\begin{array}{l}\text { Ecoscience Corp. } \\
\text { (Worcester, MA) }\end{array}$ \\
\hline Venturia inaequalis & Athelia bombacina & $\begin{array}{l}\text { Fungus, blossoming to } \\
\text { harvest }\end{array}$ & $\begin{array}{l}\text { Competition and } \\
\text { antibiosis }\end{array}$ & $\begin{array}{l}\text { Janisiewicz } \\
\text { (1991) }\end{array}$ \\
\hline
\end{tabular}

* : commercial name of the $\mathrm{BCA}$

\section{ISOLATION AND SELECTION OF BIOCONTROL AGENTS}

\subsection{Isolation and Characterisation of Epiphytic Micro-organisms}

Theoretically, the isolation procedure of potential antagonists depends on the characteristics of the infection by the pathogen. To control post-harvest diseases, investigators sually isolated naturally occurring micro-organisms from fruits just before harvesting or during storage (Aloi et al., 1991; Gullino et al., 1991b; Janisiewicz, 1991). Nevertheless, an absolute relationship between efficacy and origin of isolation doesn't exist. Actually, microorganisms exhibiting antagonistic properties against $B$. cinerea and $P$. expansum have been isolated from soil, leaves of apple tree or from fruits or leaves of other plants (Janisiewicz, 1988; Janisiewicz and Roitman, 1988; Wilson and Wisniewski, 1989). In this respect, an elegant and fast method of antagonist isolation has been adopted by Wilson et al., (1993). They applied rinsing waters from tomatoes and apples directly on wounds inoculated with the pathogen (B. cinerea) and isolated antagonistic micro-organisms from wounds which did not exhibit any symptom.

We isolated micro-organisms from rinsing waters of Golden Delicious at harvest and after different periods of storage (Jijakli, 1996). We pointed up the coexistence of filamentous fungi, yeast's and bacteria on surface of apples whatever the storage period. Fungi belonging to the genera Cladosporium, Penicillium, Aureobasidium, Alternaria, Mucor, Fusarium, Cephlosporium, Stemphylium, Trichoderma, Epicoccum, Pyrenochaeta, Pithomyces and 
Stigmella were principally observed. After two months of storage, epiphytic populations of bacteria and yeast's reached a maximum density of $5 \times 10^{7} \mathrm{cfu} / \mathrm{ml}$ and $3 \times 10^{6} \mathrm{cfu} / \mathrm{ml}$ respectively. In our study, the dominant population in term of density level was attributed to bacteria for each isolation period, while Janiciewicz (1996) observed that yeast's were the dominant population on Golden Delicious in term of different number of species.

Until now, microbial populations and their ecology on fruit surface are poorly known (Leibinger et al., 1997). A better knowledge of characteristics of epiphytic micro-organism should lead to a more rational isolation scheme of antagonists well fit to their habitat and competitive with regard to other naturally occurring micro-organisms. This gap could be explained by the lack of reliable methods to correctly take a census of micro-organism populations on the plant surface. For example, the plating method under-estimated yeast populations from rinsing tissues of plants (Fokkema, 1991), although it is still the sole technique used in the scope of postharvested fruits.

\subsection{Selection of Efficient BCA's}

Most of the investigators (Aloi et al., 1991; Gullino et al., 1991a; Janisiewicz, 1981988; Janisiewicz and Roitman, 1988; Wilson and Wisniewski, 1989) evaluated the efficacy of micro-organism strains on artificially wounded apples since in vitro antagonistic properties of a strain does not always lead to in vivo protection activity (Elsheriff and Grossmann, 1994)

Among 329 epiphytic micro-organisms (yeast's and bacteria), we selected two yeast's, Pichia anomala (strain K) (Hansen) Kurtzman and Debaryomyces hansenii (strain O) (Zopf) Lodder and Kreger-van Rij for their high and reliable biocontrol activity against infection by B. cinerea or Penicillium sp. on wounded Golden Delicious (Jijakli and Lepoivre, 1993). Treatment of wounded sites with $50 \mu \mathrm{l}$ of yeast suspension (107 cfu/ml) was sufficient to inhibit rot development induced by $50 \mu \mathrm{l}(106 \mathrm{spores} / \mathrm{ml})$ of either B. cinerea or Pencillium sp. at $5^{\circ} \mathrm{C}$ and $25^{\circ} \mathrm{C}$.

Numerous yeast strains exhibiting antagonism against Botrytis and/or Penicillium have been reported in the literature : Acremonium breve W. Gams (Janisiewicz, 1988), Candida sake (Saito and Ota) van Uden and Buckley, C. temuis Diddens and Lodder (Wilson and Wisniewski; 1989), C. oleophila (Mercier and Wilson, 1994), Candida sp. (McLaughlin et al., 1990), C. guilliermondii (Castellani) Langeron and Guerra, and Kloechera apiculata Janke (McLaughlin and Wilson, 1992), Candida sp. and Trichosporon sp. (Aloi et al., 1991, Gullino et al., 1991a), Sporobolomyces roseus Kluicer et van Niel (Janisiewicz et al., 1994). The high frequency of yeast among the antagonistic agents reported could be related to the fact that yeast's are tolerant to extreme environmental conditions of storage rooms (temperature close to $0{ }^{\circ} \mathrm{C}$, high relative humidity) and adapted to apple characteristics (high sugar concentration, high osmotic pressure and low pH) (Janicisiewicz, 1991). However, bacteria such as Bacillus subtilis (Ehrenberg) Cohn (Pusey and Wilson, 1984; Sholberg et al., 1995), Pseudomonas cepacia Palleroni et Holmes (Janisiewicz and Roitman, 1988) or P. syringae van Hall (Janisiewicz and Bors, 1995) were also reported as effective BCA's on apples against both pathogens.

\subsection{Major Parameters Controlling the Level of Protection}

The study of parameters affecting the level of protective activity under sub-optimal conditions contributes to the selection of the most efficient BCA's. This study determines also the conditions giving a high and reproducible protective activity against postharvest diseases. 
Our work (Jijakli et al., 1993b) demonstrated that antagonistic activity of different strains of yeast's, isolated from apple surface were firstly dependent on the incubation time before inoculation of B. cinerea or Penicillium sp. (Table 2). Protection level increased with time between application of the antagonist and inoculation of the pathogen. The most efficient strains, $P$. anomala (strain $\mathrm{K}$ ) and $D$. hansenii (strain $\mathrm{O}$ ) reduced significantly the diameter of decay lesion, even when inoculation of the pathogen and application of the yeast were performed simultaneously.

In other respect, there was a quantitative relationship between spore concentration of B. cinerea and the amount of antagonist required for disease control (Table 3). The application of $108 \mathrm{cfu} / \mathrm{ml}$ of $P$. anomala (strain $\mathrm{K}$ ) was necessary to completely inhibit lesions caused by B. cinerea upon inoculation with $50 \mu \mathrm{l}$ of 106 spores $/ \mathrm{ml}$ whereas $108 \mathrm{cfu} / \mathrm{ml}$ of $D$. hansenii (strain O) protected fruits against inoculation with $50 \mu \mathrm{l}$ of 105 spores $/ \mathrm{ml}$ of $B$. cinerea. The same parameters influencing the level of protection were already identified by other authors (Gullino et al., 1991b ; Janisiewicz et al., 1994 ; McLaughlin et al. ,1990 ; Mercier and Wilson, 1995 ; Roberts, 1991).

The temperature of fruit incubation and the humidity at the wound site were also identified as factors controlling the protective level (Gullino et al., 1991 a ; Mercier and Wilson, 1995). When apple wounds were artificially dried, Mercier and Wilson (1995) observed a decreased of both population level of $C$. oleophila and protection level against $B$. cinerea.

Table 2. Lesion development (mm) on wounded Golden Delicious apples treated with $50 \mu \mathrm{l}$ of antagonistic yeast suspension (about $107 \mathrm{cfu} / \mathrm{ml}$ ); and then inoculated with $50 \mu \mathrm{l}$ of pathogen suspension (106 spores $/ \mathrm{ml}$ ) after different incubation times of the antagonist (Jijakli et al., 1993a).

\begin{tabular}{|c|c|c|c|c|c|c|c|c|}
\hline \multirow[b]{2}{*}{$\begin{array}{l}\text { Incubation } \\
\text { times }\end{array}$} & \multicolumn{4}{|c|}{ B. cinerea ${ }^{b}$} & \multicolumn{4}{|c|}{ Penicillium sp. ${ }^{b}$} \\
\hline & $\mathrm{Oh}$ & $12 \mathrm{~h}$ & $24 \mathrm{~h}$ & $48 \mathrm{~h}$ & $0 \mathrm{~h}$ & $12 \mathrm{~h}$ & $24 \mathrm{~h}$ & $48 \mathrm{~h}$ \\
\hline $2.13^{\mathrm{c}}$ & $21.6^{\mathrm{a}}$ & $9.4^{d}$ & $6.9^{d}$ & $0.5^{d}$ & 20.2 & $15.6^{d}$ & $6.9^{\mathrm{d}}$ & $5.4^{d}$ \\
\hline 1.58 & 24.9 & $12.2^{d}$ & $11.2^{d}$ & $9.1^{\mathrm{d}}$ & $16.4^{d}$ & $15.6^{d}$ & 14.2 & 9.0 \\
\hline $9 \mathrm{C} 5$ & 24.7 & 19.5 & $7.0^{d}$ & $3.1^{\mathrm{d}}$ & 20.2 & 22.6 & 19.1 & 10.4 \\
\hline $5 \mathrm{~F} 2$ & 27.0 & 13.9 & $7.1^{d}$ & $19.7^{d}$ & 18.5 & $16.7^{d}$ & 15.5 & $4.1^{\mathrm{d}}$ \\
\hline $\mathrm{K}$ & $10.7^{d}$ & $8.6^{d}$ & $0.0^{d}$ & $0.1^{d}$ & $10.6^{\mathrm{d}}$ & $12.2^{\mathrm{d}}$ & $3.7^{d}$ & $0.0^{\mathrm{d}}$ \\
\hline $\mathrm{O}$ & $15.2^{\mathrm{d}}$ & $5.7^{\mathrm{d}}$ & $4.7^{\mathrm{d}}$ & $3.0^{\mathrm{d}}$ & 19.2 & 18.1 & $3.1^{d}$ & $2.0^{\mathrm{d}}$ \\
\hline $9 \mathrm{~A} 4$ & 22.0 & 19.5 & 14.1 & $5.4^{\mathrm{d}}$ & 25.4 & 22.6 & 19.2 & 14.2 \\
\hline Controle & 33.8 & 25.1 & 31.9 & 29.4 & 23.6 & 23.4 & 22.6 & 19.0 \\
\hline
\end{tabular}

a: Data represent average lesion diameter ( $\mathrm{mm}$ ) measured 5 days after pathogen inoculation.

b: Pathogen

c: Antagonistic strains

d: Means of lesion diameters of the antagonist-treated apples are significantly different $(p=0.001)$ from the control mean (in the same column) according to Dunnett's procedure.

e : Untreated apples inoculated with the pathogen only.

Data shown for 1 of the 2 trials (Data of separate trials were not pooled because variances differed significantly) 
Table 3. Lesion development ( $\mathrm{mm}$ ) on wounded Golden Delicious apples inoculated with various spores concentrations of B. cinerea or Penicillium sp. $24 \mathrm{~h}$ after treatment of different concentration of $P$. anomala (strain $\mathrm{K}$ ) or D. hansenii (strain $\mathrm{O}$ ) (Jijakli et al., 1993a).

\begin{tabular}{|c|c|c|c|c|c|c|c|c|}
\hline \multirow{2}{*}{$\begin{array}{c}\text { Yeast } \\
\text { concentration } \\
(\mathrm{cfu} / \mathrm{ml})\end{array}$} & \multicolumn{4}{|c|}{$\begin{array}{c}\text { B. cinerea spores } \\
\text { concentration (spores } / \mathrm{ml} \text { ) }\end{array}$} & \multicolumn{4}{|c|}{$\begin{array}{c}\text { Penicillium sp. spores } \\
\text { concentration }(\text { spores } / \mathrm{ml} \text { ) }\end{array}$} \\
\hline & $10^{7}$ & $10^{6}$ & $10^{5}$ & $10^{4}$ & $10^{7}$ & $10^{6}$ & $10^{5}$ & $10^{4}$ \\
\hline \multicolumn{9}{|l|}{ P. anomala } \\
\hline $10^{8}$ & $3.5^{\text {ad }}$ & $0.0^{d}$ & $0.0^{d}$ & $0.0^{\mathrm{d}}$ & $4.6^{\mathrm{d}}$ & $0.0^{d}$ & $1.1^{\mathrm{d}}$ & $0.0^{\mathrm{d}}$ \\
\hline $10^{7}$ & 4.7 & $0.7^{\mathrm{d}}$ & $1.4^{\mathrm{d}}$ & $1.6^{\mathrm{d}}$ & $9.4^{d}$ & $2.6^{d}$ & $0.0^{\mathrm{d}}$ & $3.7^{\mathrm{d}}$ \\
\hline $10^{6}$ & 17.0 & $5.2^{\mathrm{d}}$ & $10.2^{\mathrm{d}}$ & $0.0^{d}$ & $17.2^{\mathrm{d}}$ & 18.0 & 14.1 & 20.2 \\
\hline $10^{5}$ & 24.4 & $11.2^{\mathrm{d}}$ & $5.9^{d}$ & $5.0^{\mathrm{d}}$ & $18.1^{\mathrm{d}}$ & $12.9^{d}$ & 15.4 & $4.9^{\mathrm{d}}$ \\
\hline control $^{b}$ & 24.5 & 28.1 & 25.0 & 22.1 & 21.0 & 21.4 & 21.6 & 19.1 \\
\hline \multicolumn{9}{|l|}{ D. hansenii } \\
\hline $10^{8}$ & $9.5^{\mathrm{ad}}$ & $2.9^{\mathrm{d}}$ & $0.0^{\mathrm{d}}$ & $0.0^{\mathrm{d}}$ & $4.7^{\mathrm{d}}$ & $6.2^{d}$ & $8.5^{\mathrm{d}}$ & $4.6^{d}$ \\
\hline $10^{7}$ & 14.2 & $2.6^{\mathrm{d}}$ & $3.4^{d}$ & $0.0^{\mathrm{d}}$ & 15.5 & $4.0^{d}$ & $2.1^{\mathrm{d}}$ & $0.0^{\mathrm{d}}$ \\
\hline $10^{6}$ & 17.1 & $18.6^{\mathrm{d}}$ & $9.1^{\mathrm{d}}$ & $6.7^{\mathrm{d}}$ & 11.0 & 15.2 & $10.1^{\mathrm{d}}$ & $4.7^{\mathrm{d}}$ \\
\hline $10^{5}$ & 13.2 & $7.9^{\mathrm{d}}$ & $2.6^{\mathrm{d}}$ & $0.9^{d}$ & 14.9 & 16.1 & $8.4^{\mathrm{d}}$ & $9.2^{\mathrm{d}}$ \\
\hline controll $^{b}$ & 24.5 & 28.1 & 25.6 & 22.1 & 21.0 & 21.4 & 21.6 & 19.1 \\
\hline
\end{tabular}

a: Data are the average lesion diameter $(\mathrm{mm})$ measured 5 days after pathogen inoculation.

b: Untreated apples inoculated with the pathogen only.

c: Means of lesion diameters of the antagonist-treated apples are significantly different to the control mean (in the same column) according to Dunnett's procedures ( $\mathrm{p}=0.001)$

Data shown for 1 of the 2 trials (Data of separate trials were not pooled because variances differed significantly)

\section{MASS PRODUCTION OF BCA's}

A screening of the potential efficient antagonists based on their capacity to be produced and dried in mass must follow the study of the protective properties. The capacity to produce in mass and to dry the micro-organisms has to be evaluated. The cost production of a microorganism includes the culture media and the energy needed for production and drying process. Appropriate adjuvants relative to the drying process (protectants, carriers,...) must be added to increase the viability of BCA's during the different processes.

$P$. anomala (strain $\mathrm{K}$ ) and $D$. hansenii (strain $\mathrm{O}$ ) were tested for their technological properties. They were produced in fermentor (media 863) by CWBI (Centre Wallon de BioIndustrie, Gembloux, Belgium) and fermentation products were dried by lyophilisation. Both antagonistic strains can be produced in fermentor and dried while maintaining their antagonistic activity (Jijakli et al., 1993b). 
The technologies of mass production are too often neglected and published data in this area remains spare because of industrial secrets. A closer collaboration between plant pathologists and teams working on mass production and formulation of micro-organisms would greatly stimulate the crossing of BCA's from laboratory to practical use. In this respect, useful insights could be expected from research's on BCA's against insect pests and weeds (Guillon, 1993).

\section{FORMULATION OF BCA's}

A formulation has to be developed to ensure a reasonably long shelf life of the BCA's and to facilitate their preparation and their application with the standard equipment of the producer. A good formulation will protect the antagonist from adverse conditions, increase the survey and/or enhance the efficiency of micro-organisms. A formulation which reduced antagonist concentration without affecting the protective level, will improve the economical feasibility of the product.

Nutrients are frequently reported as adjuvants which stimulate or stabilise the protective level of antagonistic strains in postharvest diseases (Janisiewizc, 1994; Janisiewize et al., 1992). We selected 15 carbohydrates and 16 nitrogenous compounds as potential adjuvants of yeast formulation (Jijakli et al., 1993a). Only one sugar analogous (2-deoxy-D-glucose or 2 -gluc) showed a protective effect against $B$. cinerea when applied alone and increased the level of protection from about $60 \%$ to $90 \%$ when added to $P$. anomala (strain $\mathrm{K}$ ) or $D$. hansenii (strain $O$ ) suspension ( $105 \mathrm{cfu} / \mathrm{ml})$. The sole application of 2 -gluc inhibited also the development of $B$. cinerea on bean (Jejelowo et al., 1988). This analogous of glucose reduced in vitro spore germination and hyphal growth of $B$. cinerea and $P$. expansum (Janisiewizc 1994; Jejelowo et al., 1988; Jijakli et al., 1993a) and could act as a competitive inhibitor of glucose metabolism (Janisiewizc, 1994). 2-gluc could be a proper additive if toxicological requirements of any additive of formulation are fulfilled.

On the other hand, none of the other nutrients (L-asparagin, L-proline, galactose, mannitol, riblose and sorbitol), selected for their in vitro and/or in vivo antagonist stimulation or pathogen inhibition either by Janisiewicz et al., (1992) or Harper et al., (1981) enhanced the protective activity of $P$. anomala ( $\operatorname{strain} \mathrm{K}$ ) or $D$. hansenii (strain $\mathrm{O}$ ) in our experiments. These different results show that an effect observed in a specific plant-antagonist-pathogen combination is not automatically transposable to an other system when the nutrient affects specifically the antagonistic agents. In opposite, when the nutrient has a specific effect on basic metabolism of the pathogen with no subsequent inhibition of the antagonist, we can expect an easier transposition in different systems.

The application of calcium chloride $(2 \% \mathrm{w} / \mathrm{v})$ in mixture with $P$. anomala (strain $\mathrm{K}$ ) or D. hansenii (strain $O$ ) enhanced the protective level against $B$. cinerea and Penicillium $\mathrm{sp}$. McLaughin et al., (1990) and Gullino et al., (1991b) observed similar results when calcium is applied together with an antagonistic strain. The influence of calcium on increasing the resistance of host tissues is often reported (Conway, 1991 ; Messiaen, 1994), while its action on micro-organisms is still poorly studied. Nevertheless, the synergistic action of a combined treatment calcium-antagonis leads McLaughlin et al., (1990) to suggest the secretion of new antifungal metabolites by the BCA's. 


\section{MODE OF ACTION}

\subsection{Difficulties and Importance of the Study of Modes of Action}

As we move towards the application of biological control, new research problems are emerging among which the mechanisms of action of BCA's were too often considered only as an academic concern. The understanding of the modes of action of biocontrol agents is a prerequisite to (1) developing rational selection procedures yielding a second generation of more effective antagonistic microbial strains, (2) carrying out appropriate production and formulation enhancing antagonistic efficacy (3) providing a quality control procedure, and (4) fulfilling some requirements of the toxicological and registration procedure for commercial use.

Unfortunately, knowledge's on the mode of action of many antagonists of postharvest diseases are still limited. The comprehension of the mechanisms of action are hampered by the complex interactions between host-pathogen-antagonist. Moreover, the mechanisms studied in vitro in order to simplify these complex interactions, do not necessarily reflect in sit. reality. Nevertheless, in the absence of antibiotics production by most antagonistic yeast's, it appears that the mode of action of yeast's could comprise one or several of the following processes : nutrient or site competition, direct interactions between the biocontrol agent and the pathogen, and induced host resistance (Wilson and Wisnieswski, 1994)

\subsection{Nutrient Competition as Part of Mode of Action of P. anomala (strain $\mathrm{K}$ ) and $D$. hansenii (strain $\mathrm{O}$ ) Against B. cinerea}

Experimental evidence of the implication of nutrient competition in the antagonistic relationship is still missing although several studies suggested that competition for nutrients might play a role in the antagonistic activity. Some authors (Chalutz et al., 1991; Roberts, 1991; Wisniewski et al., 1989) highlighted the ability of antagonists to rapidly multiply at the wounded sites of fruits but without relating this aptitude to their protective activity. Results of other worker (Droby et al., 1989; Wisniewski et al., 1991) showed that the addition of nutrients can restore both the germination of the pathogen and its development on fruits in presence of the antagonist.

We also investigated the ability of $P$. anomala ( $\operatorname{strain} \mathrm{K}$ ) and $D$. hansenii (strain $O$ ) tc colonise the wounds in relation with their protective activity against $B$. cinerea on apples and with regard to the in situ conidial germination of $B$. cinerea (Jijakli et al., 1993a). Populations of $P$. anomala (strains $\mathrm{K}$ ) and $D$. hansenii (strain $\mathrm{O}$ ) in wounds increased at $25^{\circ} \mathrm{C}$ to reach a maximum density (approximately $1 \log$ unit over the initial density) after 12 hours of incubation (Figure $1 \mathrm{~A}$ and $\mathrm{B}$ ) similarly to the protection level against $B$. cinerea which also reached a maximum after 12 hours of yeast incubation.

On the other hand, in situ spore germination of $B$. cinerea was markedly reduced on wounded sites treated with strain $\mathrm{K}$ or strain $\mathrm{O}$, even when pathogen and yeast were applied simultaneously with no subsequent protection (Figure 1C). This suggested that other factor(s) than inhibition of spore gemination may be involved in biocontrol effectiveness. 


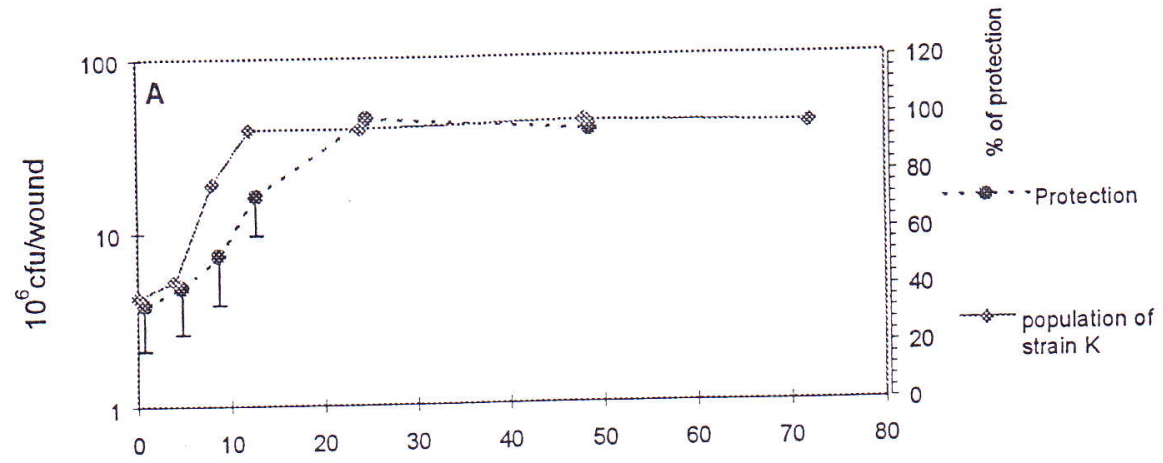

Hours after inoculation of $P$. anomala (strain $K$ )
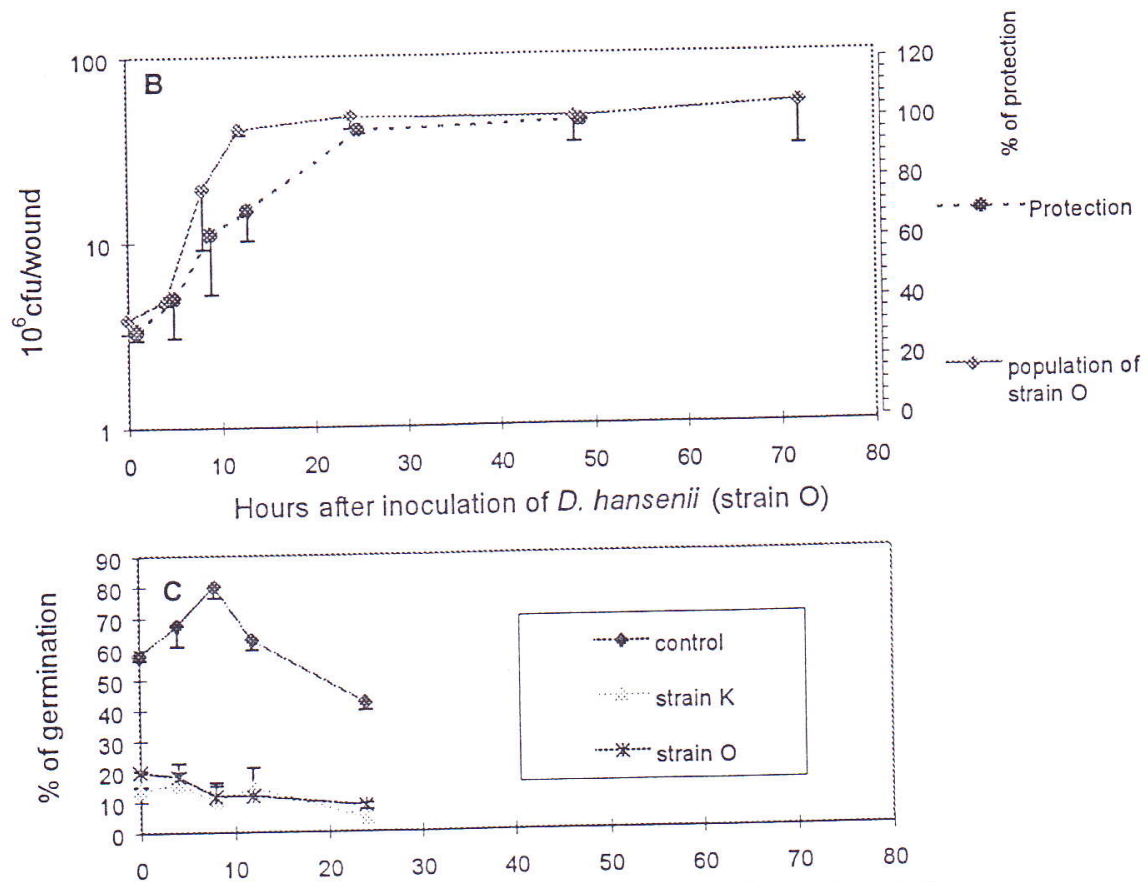

Hours elapsing between yeast application and $B$. cinerea inoculation

Hours elapsing between yeast application and $B$. cinerea inoculation

Figure 1. Effect of population densities of P. anomala (A) and D. hansenii (B) on level of protective activity against $B$. cinerea. Data from population densities represent mean colony from three trials (one wound site/trial). Each wound was triplicate-plated. Data from protection level represent the mean $\%$ of protection (as compared to the control which was not treated with yeast before inoculation of $B$. cinerea) from two trials ( 6 wounds/trial). Vertical bars represent standard error of the mean. (Jijakli et al., 1993a).

Effect of $P$. anomala and D. hansenii on spore germination (C). Data represent the mean $\%$ and associated standard error (vertical bars) of spore germination from one of the two trials ( 1 replicate per trial). Twenty fields were observed per replicate and a spore was considered as germinated when the germinating tube was longer than the spore. 


\subsection{B-1,3-glucanases as Part of Mechanism of Action P. anomala (strain K) Against B. cinerea}

Production of hydrolytic enzymes which degrade cell walls of phytopathogens has been regularly reported as a mechanism of suppression of soil borne pathogens by some biocontrol agent such as Trichoderma genus (Bélanger et al., 1995; Benhamou and Chet, 1996; Elad, 1996; Lorito et al., 1994) but lytic enzymes have rarely been reported in biological control of postharvest diseases (Wisnieswski et al., 1991).

We investigated the possible role of $\beta$-1,3-glucanases and chitinases in the antagonistic properties of $P$. anomala (strain K) against $B$. cinerea on apples (Jijakli and Lepoivre, 1998). While chitinase activities were not detected from culture filtrates of strain $\mathrm{K}$ after various growth conditions (incubation period, source of carbon), endo- (EC 3.2.1-39) and exo-ß-1,3glucanase (EC 3.2.1-58) activities were detected in the culture filtrates of strain K (Figure 2). Higher specific activities for both enzymes were obtained in media containing $2 \mathrm{~g} / 1$ of $B$. cinerea cell wall preparation (CWP) as sole carbon source as compared to media with glucose or laminarin (2 g/1). Endo- and/or exo-ß-1,3-glucanases activity from $T$. harziamum Rifai, $P$. guilliermondii Wickerham or Serratia marescens was also higher in media supplemented with fungal cell walls than in media containing laminarin (Elad et al., 1982, Ordentlich et al., 1988, Wisnieswski et al., 1991). Exoglcl, an exo-ß-1,3-glucanase purified until homogeneity from $P$. anomala (strain $\mathrm{K}$ ) culture filtrates, showed a stronger inhibitory effect on germinative tube growth than on conidial germination of $B$. cinerea (Figure 3). Moreover, the enzyme caused morphological changes such as leakage of cytoplasm and cell swelling on $B$. cinerea. Hydrolytic enzymes produced by other antagonists such as Stachybotrys elegans Barron or Schizophyllum commune Fries : Fries (Chiu and Tzean, 1995; Tweddell et al., 1995) caused similar effects on hyphal growth of Rhizoctonia solani (Künh) and Fusarium monoliforme Wollenweber.
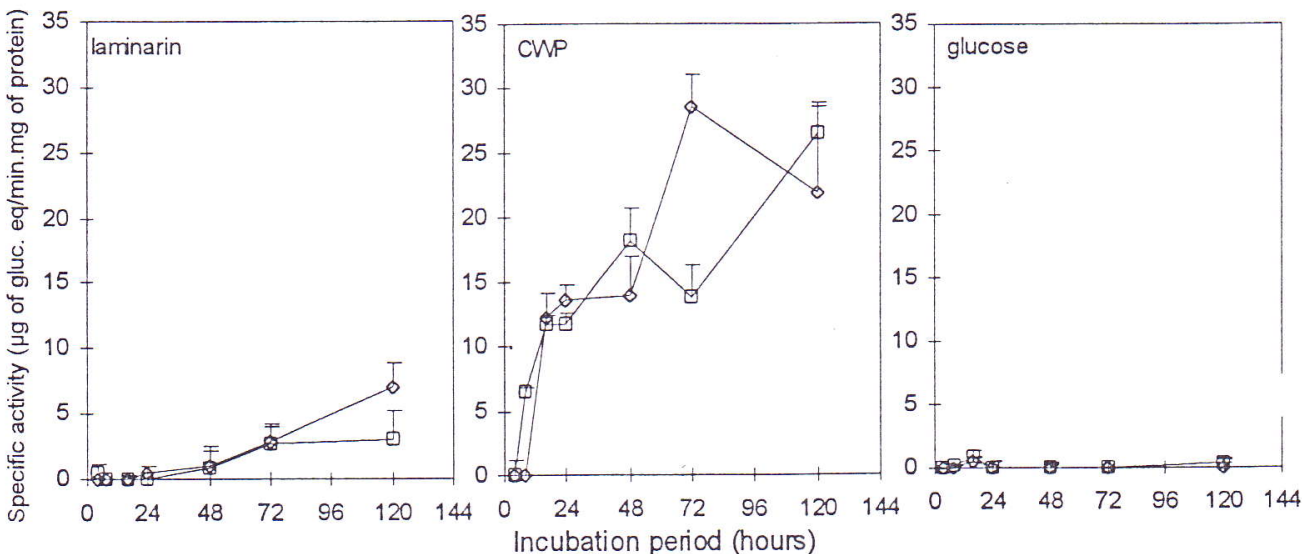

Figure 2. Time courses of endo- $\beta-1,3$-glucanase $(\diamond)$ and exo- $\beta-1,3$-glucanase $(\square)$ activity from strain $\mathrm{K}$ supernatant of YNB medium containing B. cinerea cell wall fragments (CWP), laminarin or glucose as sole carbon source $(2 \mathrm{mg} / \mathrm{ml})$. One specific unit of $\beta-1,3$-glucanase (endo-or exo-) is defined as the amount of enzyme causing the release of $1 \mu \mathrm{g}$ of glucose equivalent per miligram of protein per min. Assays were performed in triplicate and the entire experiment was repeate three times. Values presented are averages of the 3 experiments. The error bars represent standard deviations of the means of the 3 experiments (Jijakli and Lepoivre, 1998). 

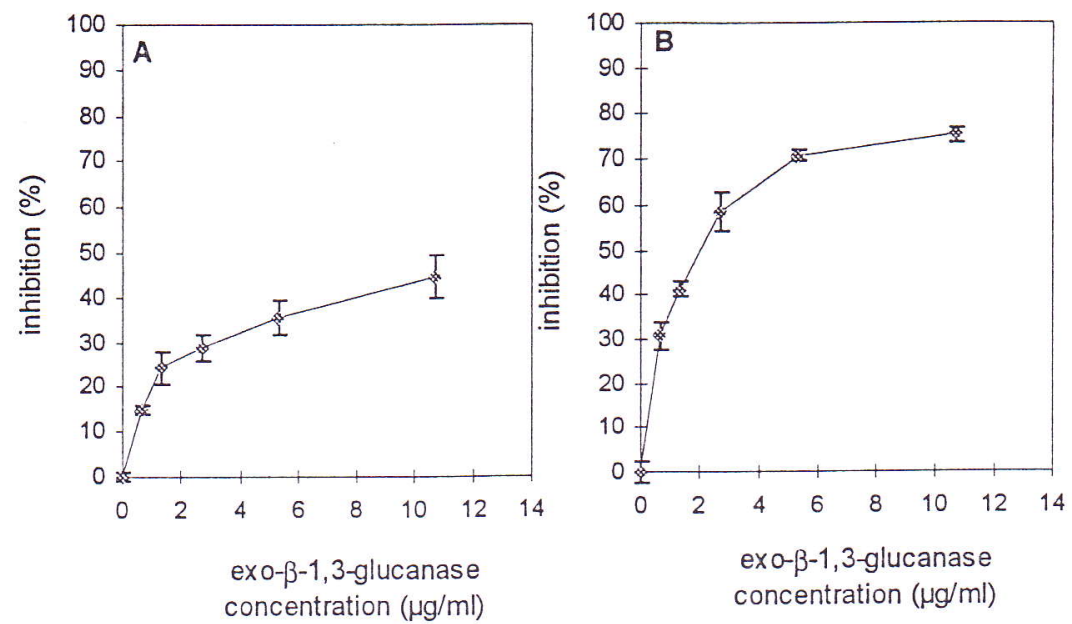

Figure 3. Effect of purified exo-B-1,3-glucanase from P. anomala on spore germination (A) and germ tube elongation (B) of $B$. cinerea.

The percentage of conidia germinating was determined as the percentage of the first 100 spores found on a microscope slide. Length of 20 germ tubes was measured and averaged. For each enzyme concentration, the mean percent of inhibition and the standard deviation (error bars) were calculated. The data collected from two separate experiments with four replicates per treatment were pooled (Jijakli and Lepoivre, 1998).

In other respect, water used to rinse apple wounds treated with strain $\mathrm{K}$ and with CWP were assayed for exo-glucanase activity (Table 4). Exo- $\beta$-1,3-glucanase activity was detected on apples treated with strain $\mathrm{K}$. That activity appears to be related to exoglcl on the basis of its electrophoretic mobility in native gel. Moreover, the addition of CWP to suspension of $P$. anomala stimulated both in situ exo- $\beta$-1,3-glucanase activity and protection level against the pathogen (Table 4). To our knowledge, this is the first demonstration of in vivo glucanases production by yeast's.

Table 4. In vivo detection of exo-B-1,3-glucanase activity from $P$. anomala strain $\mathrm{K}$ and protection from this strain against $B$. cinerea on apples (Jijakli and Lepoivre, 1998)

\begin{tabular}{lcc}
\hline Treatment ${ }^{\mathrm{x}}$ & $\begin{array}{c}\text { exo-B-1,3-glucanase activity } \\
(\mu \text { eq. gluc./wound) }\end{array}$ & $\begin{array}{c}\text { Decay lesion }(\mathrm{mm}) \\
\text { after } B \text {. cinerea } \\
\text { inoculation }\end{array}$ \\
\hline Control & $3.4 \pm 0.47 \mathrm{a}$ & $35.5 \pm 8.43 \mathrm{a}$ \\
CWP & $2.1 \pm 1.58 \mathrm{a}$ & $40.3 \pm 4.65 \mathrm{a}$ \\
Strain K & $10.8 \pm 0.52 \mathrm{~b}$ & $15.6 \pm 4.31 \mathrm{~b}$ \\
Strain K + CWP & $32.7 \pm 5.51 \mathrm{c}$ & $6.9 \pm 3.65 \mathrm{c}$ \\
\hline
\end{tabular}

$\mathrm{x}:$ Wounded sites of apples were treated with $50 \mu \mathrm{l}$ of distilled water (Control and CWP) or $50 \mu \mathrm{l}$ of strain K suspension $(105 \mathrm{cfu} / \mathrm{ml}$ ) (Strain K). After 24 hours, $50 \mu \mathrm{l}$ of CWP were applied at the wound sites (CWP and strain $\mathrm{K}+\mathrm{CWP})$. Treatments were arranged in a total randomized design.

$y: 24 \mathrm{~h}$ after treaments, exo- $\beta-1,3$-glucanase activities were measured. Means of enzymatic activity ( \pm standard deviation) were expressed as $\mu \mathrm{g}$ equivalent of glucose/wound. Treatments were arranged in a total randomized design (three replicates per treatment). The experiment was conducted three separate times. After analysis of variance (ANOVA), data from the three experiments were pooled. Resulting means with a common letter do not differ significantly at $P=01$ (Fisher's LSD).

$\mathrm{z}: 24 \mathrm{~h}$ after treaments, wounded sites were inoculated with B. cinerea suspension (106 spores $/ \mathrm{ml}$ ). Treatments were arranged in a total randomized design. The experiment was conduted in two replicates searately. After analysis of variance (ANOVA), data from the two experiments were pooled. Resulting means were separated by the Ficher's LSD at $\mathrm{P}=0.01$. 
The possible production of exoglcl on apples and its effect on $B$. cinerea in vitro strengthen the hypothesis that exo- $\beta-1,3$-glucanase contributes to the biocontrol of B.cinerea by P.anomala strain $\mathrm{K}$ without demonstrating its action. The following criteria may be used to determine if a particular compound is directly involved in biological control of fungal pathogens : (1) the purified compound shows fungicidal or antimicrobial properties, (2) the compound may be detected in situ, when producing strains are present, (3) the biocontrol ability of mutants defective in compound of interest is reduced in the laboratory and in practical conditions, (4) the complementation of the mutant with DNA sequence restoring the synthesis of the compound of wild strain restores also biocontrol ability. Because of an easier way to engineer prokaryotes, all of these criteria have been already used to determine the involvement of metabolites produced by antagonistic bacteria (Glick and Bashan, 1997; Wilson and Wisnieswski, 1994). In opposite, the criteria involving molecular tools were not yet reported to support the implication of a compound produced by antagonistic yeast's. Moreover, their possible polyploidy complicates the genetic investigations. However, in contrast to most other organisms, integrative recombination of transforming DNA in yeast's proceeds exclusively via homologous recombination and that property constitutes the basis of our further investigations on the mechanisms of biocontrol of $P$. anomala (strain $\mathrm{K}$ ).

We isolated two exo- $\beta$-1,3-glucanases encoding genes from a $P$. anomala (strain $\mathrm{K}$ ) genomic library (Grevesse et al., 1998). These genes named PAEXG1 and PAEXG2 were found to share significant similarities at the deduced amino acid level with exo- $\beta-1,3$-glucanases from other fungi. Evidence that $P A E X G 2$ coded for the purified exoglc1 was given by the sequencing of the $\mathrm{N}$-terminal region of exoglc 1 . Because possible allelic effects render genetic studies more complicated, $P$. anomala (strain $\mathrm{K}$ ) isolated from an apple in its diploid form, was induced to sporulate and ascospores were isolated by micromanipulation. Segregation of PAEXG1 and PAEXG2 in 10 haploid segregants was studied by Southern blots in relation with their in vitro exo- $\beta-1,3$-glucanase activity production and their in vivo protective activity against $B$. cinerea. All segregants showed an exo- $\beta-1,3$-glucanase activity production equivalent to the production of the diploid strain (or even higher) and retained some significant biocontrol activity at a lower or equivalent level in comparison with the diploid strain. No relation was found between these properties and the segregation of PAEXG1 or PAEXG2 showing that either $P$. anomala (strain $\mathrm{K}$ ) is homozygous at both loci and/or other genetic factors (genes or regulatory elements) are active in the protective effect. The implication of $P A E X G 1$ and PAEXG2 in the antagonism will be studied in vivo by their disruption through integrative transformation in the genome of the haploid material. This disruption strategy will give the experimental evidence for the hypothetical action of exo- $\beta-1,3$-glucanase in the protective properties of $P$. anomala (strain $\mathrm{K}$ ).

\section{INTEGRATION OF BIOLOGICAL CONTROL TO OTHER TREATMENTS AGAINST DISEASES ON APPLES}

The complete substitution of pesticides by biological control does not constitute a realistic goal. Biological control must be considered like a new potential strategy to be integrated to a panel of other methods. In this respect, the compatibility of BCA's treatments must be firstly evaluated with regard to their integration to the succession of fruit conditioning operations before storage.

A first strategy to widen the spectrum of antagonistic action consists in mixing several BCA's (Falconi and Megden, 1994; Janisiewicz, 1996; Leibinger et al., 1997). A higher protection of postharvest apples against $P$. expansum was observed with the application of a 
mixture of $S$. roseus and $P$. syringae in comparison with the effects of their separate application (Janisiewicz and Bors, 1995). The development of five different wound diseases on pears was totally controlled by the treatment of yeast combination [Cryptoccocus laurentii (Kufferath) Skinner, C. infirmo-miniatus (Okunuki) Phaff and Fell and Rhodotorula glutinis (Fresenius) Harrison] (Chand-Goyal and Spotts, 1996)

The combination of chemical treatments with BCA's was more efficient than the application of the sole antagonistic micro-organsism. The success of biocontrol integration to chemical treatments will depends on the selection of the best combinations of fungicide-waxantagonist (Pusey, 1986). The compatibility of a strain of P. guilliermondii with a commercial wax and a fungicide (thiabendazole) was evaluated against $P$. digitatum on postharvest citrus (Droby et al., 1993). Other investigators observed the same phenomenon with other biochemical treatments (McGuire, 1994 ; Chand-Goyal and Spotts, 1996). In some cases, the combination of biological and chemical applications allowed the reduction of chemical concentration (Droby et al., 1993).

The integration of the biological agents to other physical measures (thermotherapy, gamma and UV irradiation, film-forming polymers treatments) could be an other solution to widen the spectrum of activity of BCA's (Wilson et al., 1994).

The grower attitude will depend on the capacity of non chemical strategy to inhibit both latent and wound infections usually targeted by traditional fungicide treatments. The control of Gloeosporium infections developing postharvest apple rots from orchard latent infections, has to be assumed on postharvest apples in addition to the protection of wound pathogens (Botrytis and Penicillium) (Jijakli and Lepoivre, 1995). In this context, heat treatments with water $\left(45^{\circ} \mathrm{C}\right.$ for $\left.10 \mathrm{~min}\right)$ appeared to be efficient against Gloeosporides lenticel infections (C. gloeosporioides, C. malicorticis and T. fructigena) by inactivation of spores or hyphae located on skin and on external part of fruit flesh (Bondoux, 1992 ; Eckert, 1975). However, thermotherapy treatment with water bath can enhance the sensitivity of apples to wound pathogens such as Alternaria sp., B cinerea or P. exansum (Edney and Burchill, 1967).

In order to integrate biological control to thermotherapy, we applied three different treatments separately or in combination on postharvest Golden Delicious: (1) dipping the apples in water at $45^{\circ} \mathrm{C}$ for $10 \mathrm{~min}$, (2) dipping the fruits for $2 \mathrm{~min}$ in a water suspension of two antagonistic yeast's, Pichia anomala (strain K) and Candida sake (strain O) $(107 \mathrm{cfu} / \mathrm{ml}$ each), or (3) dipping the fruits in an emulsion of a $2 \%$ film-forming antitranspirant ( $2 \% \mathrm{Nu}$ film-P or NFP, $96 \%$ of poly-1-p-Menthen, Miller laboratory) for 2 min. Thermotherapy alone reduced the incidence of Gloeosporides lenticel infections from $54.4 \%$ (untreated apples) to $4.6 \%$, but enhanced sensitivity of the apples to Penicillium spp (Table-5). The higher sensitivity to Penicillium infections could be explained by lenticel damage (Edney and Burchill, 1967) or partial sterilization of fruit surface enhancing the subsequent Penicillium contamination. Control of this pathogen was restored by dipping the fruits in yeast suspension in NFP emulsion after the heat treatment. The quality parameters (weight, size, skin color, firmness, acidity and refractometric indice) of the fruits were not affected by any of the treatments (Jijakli et al., 1993a). During a second year of trials, combination of heat treatment and yeast application could entirely control infections caused by B. cinerea and Gloeosporium rot and the percentage of apples rotted by Penicillium spp. was reduced from $18.2 \%$ (untreated fruits) to $3.8 \%$ without affecting any quality parameters (Table- 6 ), thus confirming the efficacy of such integrated treatments ainst major fungal diseases on postharvest apples. Nevertheless, the evaluation of the practical feasibility of an integrated approach combining biological control and thermotherapy must be further studied with a less intensive scheme of chemical application. 
Table 5. Separate and combined effects of thermotherapy, biological control and antitranspirant application on post-harvest diseases of apples in 1993 (Jijakli et al., 1993b)

\begin{tabular}{lrrrrrrrr}
\hline & Control & $45^{\circ} \mathrm{C}^{\mathrm{b}}$ & $\begin{array}{r}45^{\circ} \mathrm{C} \\
+\mathrm{NFP}^{\mathrm{c}}\end{array}$ & $\begin{array}{r}45^{\circ} \mathrm{C} \\
\mathrm{K}+\mathrm{O}^{d}\end{array}$ & $\begin{array}{r}45^{\circ} \mathrm{C}+ \\
\mathrm{K}+\mathrm{O}+ \\
\mathrm{NFP}\end{array}$ & $\mathrm{K}+\mathrm{O}$ & $\begin{array}{r}\text { NFP } \\
\text { NFP+ } \\
\mathrm{K}+\mathrm{O}\end{array}$ \\
\hline Total infection & $72.4 \mathrm{a}$ & 55.2 & 61.3 & 50.0 & 40.2 & 56.2 & 57.5 & 62.5 \\
Gloeosporides & 54.4 & 4.6 & 4.6 & 2.3 & 1.5 & 37.7 & 33.8 & 41.5 \\
Penicillium spp. & 8.2 & 20.0 & 32.3 & 19.2 & 11.5 & 3.1 & 10.0 & 6.1 \\
Alternaria spp. & 4.8 & 13.1 & 10.0 & 10.8 & 11.5 & 4.6 & 5.4 & 7.7 \\
Fusarium spp. & 3.4 & 7.7 & 5.4 & 3.1 & 6.9 & 0.8 & 0.8 & 2.3 \\
Cylindrocarpon spp. & 3.4 & 3.8 & 3.8 & 5.4 & 6.9 & 3.8 & 1.5 & 3.8 \\
Rhizopus spp. & 0.0 & 1.5 & 0.0 & 0.0 & 0.0 & 0.0 & 0.0 & 0.0 \\
Non determined & 4.1 & 8.5 & 11.5 & 9.2 & 9.2 & 10.0 & 10.0 & 6.9 \\
\hline
\end{tabular}

$a=$ mean percentage of infection from 130 apples, $b=$ apples were dipped in heat water $\left(45^{\circ} \mathrm{C}\right)$ for $10 \mathrm{~min}$,

$\mathrm{c}=$ apples were dipped in Nu-Film-P $(2 \%), \mathrm{d}=$ apples were dipped in strain $\mathrm{K}$ et $\mathrm{O}$ suspensio (107 cfu of each strain/ml)

Table 6. Separate and combined effects of thermotherapy, biological control and antitranspirant application on post-harvest diseases of apples in 1994

\begin{tabular}{lcc}
\hline & Control & $45^{\circ} \mathrm{C}+\mathrm{K}+\mathrm{O}+\mathrm{NFP}^{\mathrm{b}}$ \\
\hline Total infection & $24.2 \mathrm{a}$ & 4.6 \\
Gloeosporides & 1.5 & 0.0 \\
Penicillium spp. & 18.2 & 3.8 \\
Botrytis cinerea & 6.1 & 0.0 \\
Fusarium spp. & 0.0 & 0.0 \\
Alternaria spp. & 0.0 & 0.0 \\
Non determined & 0.8 & 0.8 \\
\hline
\end{tabular}

$\mathrm{a}=$ mean percentage of infection from 130 apples, $\mathrm{b}=$ apples were successively dipped in heat water $\left(45^{\circ} \mathrm{C}\right)$ for $10 \mathrm{~min}$ and in a suspension of yeast's in a $2 \%$ NFP emulsion, $\mathrm{c}=$ dry heat treatment carried out at $38^{\circ} \mathrm{C}$ for $24 \mathrm{~h}, \mathrm{~d}=$ apples were successively heated in a steam room and dipped in a suspension of yeast's in a $2 \%$ NFP emulsior

\section{HOMOLOGATION}

Biological agents used for the control of plant diseases are primarily living organisms. The impact on the environment and therefore, safety requirements are likely to be somewhat different than those for chemical pesticides.

OECD, with particular inputs from the Directorate of Sciences and Technology and Environment, published a booklet which concerned the release of micro-organisms in the environment. Most countries, including the European Union, have incorporated the main conclusions of the OECD reports (OECD, 1995) in their national regulation.

In this respect, the European Union Council Directive of 15 July, 1991 (91/414/EEC) concerns the marketing of plant protection products. According to this directive, any products used in the biological control of plant diseases must be considered as plant protection products 
and have therefore to fulfil different specific requirements. The technical dossier of registration of the BCA must supply the necessary information's for evaluating the foreseeable risks, whether immediate or delayed, which the substance may entail for humans and the environment. These requirements mainly concern the identity of the organism, its biological properties, the description of the analytical methods available for its identification, its toxicological impact (pathogenicity and infectivity), and the ecotoxicological properties. The associated costs for the registration of plant protection products containing biological agents are directly related to the level of requirements and rapidly become so high that the development of products for the biological control of plant disease could be discouraging for companies and leads into temptation of circumventing these regulations. Public policy could thus promote biological alternative to chemical control by authorising realistic registration procedures based on a case by case study. If the active substance belongs to a group of micro-organisms well known for their non pathogenicity, different costly studies such as long term toxicity should be not required for the evaluation of the dossier. While the responsibility of the registration usually falls upon the company developing a commercial product, some requirements also concern the criteria of the screening tests set up for the selection of the agents. In this respect, we must

uphasise possible problems encountered in the registration of BCA's whose mode of action include antibiosis or that belong to groups of micro-organisms comprising some potential pathogenic species or strains.

Large scale introduction of biocontrol agents also requires specific evaluation of their environmental impact. A requisite to any study related to the persistence of artificially introduced micro-organisms in the environment is the ability to track them. In this purpose, molecular fingerprinting of P.anomala (strain $\mathrm{K}$ ) was attempted by means of random amplification of DNA (RAPD). Polymorphism was observed in the RAPD profiles of different strains of P.anomala and between different species of yeast. The nucleotide sequence of a strain K-specific amplified product was used to design specific primers which allow the unequivocal recognition of the antagonist. That method primarily used for identification of the BCA and monitoring its population on the fruit surface, could also be used to perform studies of ecophysiology of the BCA, with the aim of understanding and predicting its antagonistic activity as affected by environmental conditions of storage of the fruits.

\section{CONCLUSIONS}

Many challenges must be met before biocontrol of postharvest diseases can be sucssfully used on a commercial basis (Figure 4). Biological control is often generating a great enthusiasm although the still limited relevance of BCA today. The postharvest environment may be one in which the best chance to develop successful biological control exists because many aspects of it can be controlled. Moreover, consumer demand for alternatives to postharvest chemical treatments constitutes a major and special impetus in the search for biocontrol agents. Already commercially available products (such Aspire ${ }^{\mathrm{TM}}$ and Biosave ${ }^{\mathrm{TM}}$ ) demonstrate the realism of the approach.

However, encouragement's from environmental agencies and central government as well as grower education remain crucial in determining the economic climate within biological control will operate.

It remains doubtful that the first generation of biocontrol agents will easily provide by themselves the efficacy and the consistency associated with conventional fungicides. However, biocontrol agents already selected in different laboratories could constitute a significant part of integrated systems including physical treatments or lower doses of chemicals to provide adequate control of postharvest diseases. 


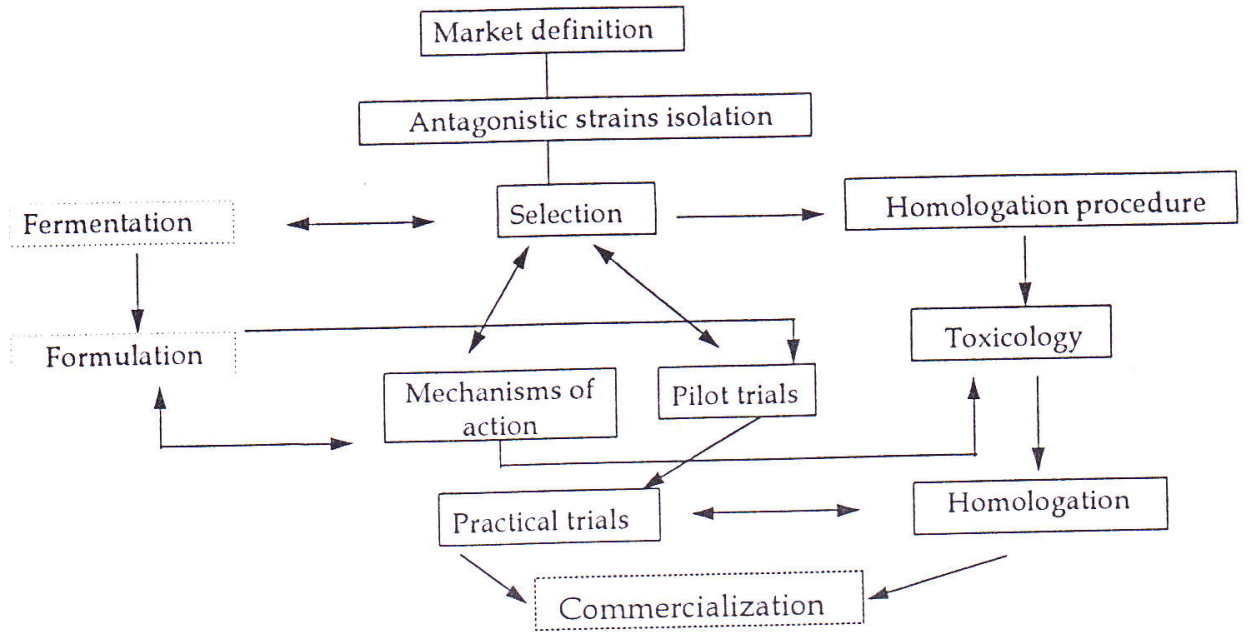

Figure 4. Steps leading to the practical use of BCA's

In the long term, basic information's on the genetically determined factors that control survival, colonisation, effectiveness in the field and storage and properties of mass production are required to overcome the random process of selection.

\section{ACKNOWLEDGEMENTS}

This work has been as a part of the "CAMAR" project "Biological control of rot diseases of fruit and vegetable crops" funded by EC.

\section{REFERENCES}

Aloi, C., Benzi, D., Testoni, A. and Gullino, M. L. 1991, Biological control of postharvest diseases of apple : experimental results, in : ANPP-Third International Conference on Plant Diseases, Tome II. Ministère de l'Agriculture et Ministère de la Recherche et de la Technologie, Bordeaux, France pp. 695-702

Belanger, R. R., Dufour, N., Caron, J. and Benhamou, N. 1995, Chronological events associated with the antagonistic propreties of Trichoderma harzianum against Botrytis cinerea : indirect evidence for sequential role of antibiosis and parasitism, Biocontrol Science and Technology 5: 41-53.

N and Chet I 1996. Parasitism of sclerotia of Sclerotium rolfsii by Trichoderma harzianum ultrastructural and cytochemical aspects of the interaction, Phytopathology $86: 405-416$

Bondoux, P., (ed.), 1992, Maladies de conservation des fruits à pépins, pommes et poires, INRA et PHM revue horticole, Paris, France

Chalutz, E. and Droby, S. 1993, Mechanisms of antagonisms of yeasts against postharvest diseases, in : Biologica Control of Fruit and Foliar Disease, P. Lepoivre, ed., Proceedings of an EC Workshop, Gembloux, Belgium pp. 67-76.

Chalutz, E., Droby, S., Cohen, L., Weiss, B., Barkai-Golan, R., Daus, A. and Fushs, Y. 1991, Biological control of Botrytis, Rhizopus and Alternaria rots of tomato fruit by Pichia guillermondii, in : Proccedings of Intemational Workshop on Biological Control of Postharvest Diseases of Fruits and Vegetables, USA-USDA Publ. ARS-92, Shepherdstown, West Virginia, USA pp. 71-85.

Chand-Goyal, T. and Spors, R. A. 1996, Control of postharvest pear diseases using natural saprophytic yeast colonies and their combination with a low dosage of thiabendazole, Postharvest Biology and Technology 7: 51-64 
Chiu, S. C. and Tzean, S.S. 1995, Glucanolytic enzyme production by Schizophyllum commune Fr. during mycoparasitisme, Physiological and Molecular Plant Pathology 46: 83-94.

Conway, W. S. 1991, Postharvest calcium treatment of apple fruit to provide broad-spectrum protection against postharvest pathogens, Plant Diseases 75: 620-622.

Droby, S., Chalutz, E., Wilson, C. L. and Wisniewski, M. 1989, Characterization of the biocontrol activity of Debarryomyces hansenii in the control of Penicillium digitatum on grapefruit, Can. J. of Microbio. 35: $308-313$

Droby, S., Hofstein, R., Wilson, C. L., Wisniewski, M, Fridlender, B., Cohen, L., Weiss, B., Daus, A., Timar, D. and Chalutz, E. 1993, Pilot testing of Pichia guilliermondii : a biocontrol agent of postharvest diseases of Citrus fruit, Biological Control 3: 47-52.

Eckert, J.W 1975, Postharvest diseases of fresh fruits and vegetables - Etiology and control, in : Symposium Postharvest Biology and Handling of Fruits and Vegetables, N.F. Haard and D.K. Salunkhe, eds., The AVI Publishing Company Inc., Westport, Connecticut, USA pp. 81-117.

Edney, K. L. and Burchill, R. T. 1967, The use of heat to control the rotting of Cox's Orange Pippin apples by Gloeosporium spp., Annals of Applied Biology 59: 389-400.

Elad, Y. 1996, Mechanisms involved in the biological control of Botrytis cinerea incited diseases, European Journal of Plant Pathology 102: 719-732

Elad, Y., Chet, I. and Henis, Y. 1982, Degradation of plant pathogenic fungi by Trichoderma harzianum, Can. J. Microbio. 28: 719-725.

Elsherif, M. and Grossmann, F. 1994, Comparative investigations on the antagonistic activity of fluorescent pseudomonas against Gaeumannomyces graminis var. tritici in vitro and in vivo, Microbiol. Res. 149: 371-377.

Falconi, J. and Mengden, K. 1994, Eppiphytic fungi on apples leaves and their value for control of the postharvest pathogens Botrytis cinerea, Monilia fructigena and Penicillium expansum, J. Pl. Dis. Protec. 1: 3847 .

Filonow, A.B., Vishniac, H. S., Anderson J. A. and Janisiewicz, W. J. 1996, Biological control of Botryti. cinerea in apple by yeasts from various habitats and their putative mechanisms of antagonism, Biological control 7: 212-220

Fokkema, N. J. 1991, The phyllosphere as an ecologically neglected milieu : a plant pathologist's point of view, in : Microbial Ecology of Leaves, J. H. Andrews and S. S. Hirano, eds., Springer-Verlag, Madison, USA pp. 3-18.

Franclet, J. 1994, Enquête ANPP - Maladies de conservation des pommes, L'arboriculture fruitière 473: 24 26.

Glick, B. R. and Bashan, Y. 1997, Genetic manipulation of plant growth-promoting bacteria to enhance biocontrol of phytopathogens, Biotech. Adv. 15: 353-378.

Grevesse, C., Jijakli, M. H., Duterme, O., Colinet, D. and Lepoivre, P. 1998, Preliminary study of exo-B-1,3glucanase encoding genes in relation to the protective activity of Pichia anomala (strain $\mathrm{K}$ ) against Botrytis cinerea, Proceedings of the Workshop on Molecular Approaches in Biological Control, Délemont, Suisse, (in press)

Guillon, M. 1993, Formulation of biopesticides, an industrial view of biological agents, in : Biological Control of Fruit and Foliar Disease, P. Lepoivre, ed., Proceedings of an EC Workshop, Gembloux, Belgium pp. $99-106$

Gullino, M. L., Aloi, C. and Garibaldi, A. 1991a, Integrated control of grey mould of tomato, IOBC/WPRS Bulletin : Integrated control in protected crops under mediterranean climate 14, pp. 211-215

Gullino, M.L., Aloi, C., Benzy, D. and Garibaldi, A. 1991b, Attempts at biological control of postharvest diseases of apple, Med. Fac. Landbouw, Univ. gent 56: 195-202

Harper, A. M., Strange, R. N. and Langcake, P. 1981, Characterization of the nutrients required by Botrytis cinerea to infect broad bean leaves, Physiological Plant Pathology 19: 153-167.

Janisiewicz, W. 1987, Postharvest biological control of blue mold on apples, Phythopathology 77: 481-485.

Janisiewicz, W. 1988, Biocontrol of postharvest diseases of apples with antagonist mixtures, Phytopatology 78: $194-198$.

Janisiewicz, W. 1991, Biological control of postharvest fruit diseases, in : Handbook of Applied Mycology, Volume 1, D.K. Arora, B. Rai, K.G. Mukerji and G. R. Knudsen, eds., Marcel Dekker, Inc., New York, USA pp. 301-325.

Janisiewicz, W. 1994, Enhancement of biocontrol of blue mold with the nutrient analog 2-deoxy-D-glucose on apples and pears, Appl. Environ. Microbiol. pp. 2671-2676

Janisiewicz, W. 1996, Ecologica diversity, niche overlap, and coexitence of antagonists used in developing mixtures for biocontrol of postharvest diseases of apples, Phytopathology 86: 473-479.

Janisiewicz, W. and Bors, R. 1995, Development of a microbial community of bacterial and yeast antagonists to control wound-invading postharvest pathogens of fruits, Appl. Environ. Microbiol. pp. 3261-3267.

Janisiewicz, W. and Roitman, J. 1988, Biological control of blue mold and gray mold on apple and pear with 
Pseudomonas cepacia, Phytopathology 78: 1697-1700.

Janisiewicz, W., Peterson, D. L. and Bors, R. 1994, Control of storage decay of apples with Sporobolomyces roseus, Plant Diseases $78: 466-470$.

Janisiewicz, W., Usall, J. and Bors, B. 1992, Nutritional enhancement of biocontrol of blue mold on apples, Phytopathology 82: 1364-1370.

Jejelowo, O. A., Epton, H. A. S. and Trinci, A. P. J. 1988, Effects of paramorphogens and 2-deoxy-D-glucose on development of lesions of Botrytis fabae on Vicia faba, Trans. Br. Mycol. Soc. 91: 661-669.

Jijakli, M. H. 1996, Etudes des propriétés antagonistes de deux souches de levures vis-à-vis de Botrytis cinerea Pers. sur pommes en conservation, Thèse de doctorat, Faculté Universitaire des Sciences Agronomiques, Gembloux, Belgium.

Jijakli, M. H. and Lepoivre, P. 1993, Biological control of postharvest Botrytis cinerea and Penicillium on apples, IOBC/WPRS Bulletin : Biological Control of Foliar and Post-Harvest Diseases 16, pp. 106110.

Jijakli, M. H. and Lepoivre, P. 1995, Utilisation de biopesticides pour la protection des pommes en conservation, Le Fruits Belge 445: 83-88.

Jijakli, M. H. and Lepoivre, P. 1998, Characterization of an exo-ß-1,3-glucanase produced by Pichia anomala strain K, antagonist of Botrytis cinerea on apples, Phytopatholgy (in press).

Jijakli, M. H., Lepoivre, P., Tossut, P. and Thonart, P. 1993a, Biological control of Botrytis cinerea and Penicillium on postharvest apples by two antagonistic yeasts, Med. Fac. Landbouw, Univ. Gent. 58: 1349-1358.

Jijakli, M.H., Choutka, C. and Lepoivre, P. 1993b, Formulation and integrated use of two antagonistic yeas to postharvest treatments against diseases on apples, in : Biological Control of Fruit and Foliar Disease, P. Lepoivre, ed., Proceedings of an EC Workshop, Gembloux, Belgium pp. 107-117.

Leibinger, W., Breuker, B., Hahn, M. and Mengden, K. 1997, Control of postharvest pathogens and colonization of the apple surface by antagonistic microorganisms in the field, Biological Control 87: 1103-1110.

Lorito, M., Hayes, C. K., Di Pietro, A., Woo, S. L. and Harman, G. E. 1994, Purification, characterization and synergisic activity of a glucan 1,3-b-glucosidase and an $\mathrm{N}$-acetyl-b-glucosaminidase from Trichoderma harzianum, Phytopathology 84: 398-405.

McGuire, R. G. 1994, Application of Candida guilliermondii in commercial citrus coatings for biocontrol of Penicillium digitatum on grapefruits, Biological Control 4: 1-7.

McLaughlin, R. J. and Wilson, C.L. 1992, Biological control of postharvest diseases of grape, peach and apple with the yeasts Kloeckera apiculata and Candida guilliermondii, Plant Diseases 76: 470-473.

McLaughlin, R. J., Wisniewski, M. E., Wilson, C. L. and Chalutz, E. 1990, Effect of inoculum concentration and salt solutions on biological control of postharvest diseases of apple with Candida sp., Phytopathology 80: 456-461

Mercier, J. and Wilson, C. L. 1994, Colonization of apple wounds by naturally occurring microflora and introduced Candida oleophila and their effect on infection by Botrytis cinerea during storage, Biological Control 4: 138-144

Mercier, J. and Wilson, C. L. 1995, Effect of wound moisture on the biocontrol by Candida oleophila of gray mold rot (Botrytis cinerea) of apple, Postharvest Biology and Technology 6: 9-15.

Messiaen, J. 1994, La transduction du signal chez les végétaux supérieurs en réponse à une attaque pathogène : Identification de réponses membranaires, cytosoliques et nucléaires induites par des olgogalacturonides, Thèse de doctorat, Presse Universitaire de Namur, Belgium.

OECD, 1995, Safety consideration for biotechnology : scale-up of crops plants, OECD, Paris, France.

Ordentlich A., Elad, Y. and Chet, I. 1988, The role of chitinase of Serratia marescens in biocontrol of Sclerotium rolfsii, Phytopathology 78: 84-88.

Piano, S., Neyrotti, V., Migheli, Q. and Gullino, M.L. 1997, Biocontrol capability of Metschnikowia pulcherrima against Botrytis postharvest rot of apple, Postharvest Biology and.Technology 11: 131-140.

Pusey, P. L. 1986, Compatibility of Bacillus subtilis for postharvest control of peach brown rot with commercial fruit waxes, Dicloran and cold-storage conditions, Plant Diseases 70: 587-590.

Pusey, P. L. and Wilson, C. L. 1984, Postharvest biological control of stone fruit brown rot by Bacillus subtilis, Plant Diseases 68: 753-756.

Roberts, R. G. 1991, Postharvest biological control of gray mold of apple by Cryptococcus laurentii, Phytopathology 80: 1051.

Rosenberger, D.A. 1991, Postharvest diseases (Blue mold- Gray mold), in : Compendium of Apple and Pear Diseases, A.L. Jones and H.S. Aldwinckle, eds., APS Press The American Phytopathological Society, USA pp. 53-58.

Sholberg, P. L., Marchi, A. and Bechard, J. 1995, Biocontrol of postharvest diseases of apple using Bacillus spp. isolated from Hored apples, Can. J. Microbiol.41: 247-252.

Tronsmo, A. and Ystaas, J. 1980, Biological control of Botrytis cinerea on apple, Plant Diseases 64: 1009.

Tweddell, R. J., Jabaji-Hare, S. H. and Charest, P. M. 1995, Production of chitinases and b-1,3-glucanases by 
Stachybotrys elegans, a mycoparasite of Rhizoctonia solani, Appl. Environ. Microbiol. pp. 489-495. Wellings, P. W. 1996, The role of public policy in biological control : some global trends, Entomophaga 41 :
435-441.

Wilson, C. L. and Wisnieswski, M. E., (eds.), 1994, Biological Control of Postharvest Diseases : Theory and Practice, CRC Press, London, UK.

Wilson, C. L. and Wisniewski, M. E. 1989, Biological control of postharvest diseases of fruits and vegetables : an emerging technology, Annual Review Phytopathology 27: 425-441.

Wilson, C. L., El Ghaouth, A., Chalutz, E., Droby, S., Stevens, C., Lu, J. Y., Khan, V. and Arul, J. 1994 Potential of induced resistance to control postharvest diseases of fruits and vegetables, Plant Diseases
78: 837-844.

Wilson, C. L., Wisniewski, M.E., Droby, S. and Chalutz, E. 1993, A selection strategy for microbial antagonists to control postharvest diseases of fruits and vegetables, Scientia Horticulturae 53: 183-189.

Wisniewski, M. E., Wilson, C. L. and Hershberger, W. S. 1989, Characterization for inhibition of Rhyzopus stolonifer germination and growth by Enterobacter cloacea, Can. J. Bot. 67: 2317-2323.

Wisniewski, M., Biles, C., Droby, S., McLaughlin, R., Wilson, C. and Chalutz, E. 1991, Mode of action of the postharvest biocontrol yeast, Pichia guillermondii, I, Characterization of attachment to Botrytis cinerea, Physiol. Mol. Pl. Path. 39: 245-258 